Utah State University

DigitalCommons@USU

Co

Bee Lab

5-7-1914

\title{
Names applied to the North American Bees of the Genera Lithurgus, Anthidium, and Allies
}

T. D. A. Cockerell

University of Colorado

Follow this and additional works at: https://digitalcommons.usu.edu/bee_lab_co

Part of the Entomology Commons

Recommended Citation

Cockerell, T. D. A., "Names applied to the North American Bees of the Genera Lithurgus, Anthidium, and Allies" (1914). Co. Paper 528.

https://digitalcommons.usu.edu/bee_lab_co/528

This Conference Paper is brought to you for free and open access by the Bee Lab at DigitalCommons@USU. It has been accepted for inclusion in Co by an authorized administrator of DigitalCommons@USU. For more information, please contact digitalcommons@usu.edu.

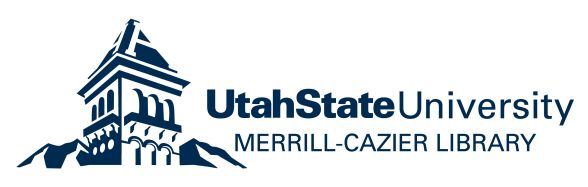


NAMES APPLIED TO THE NORTH AMERICAN BEES OF THE GENERA LITHURGUS, ANTHIDIUM, AND ALLIES

T. D. A. COCKERELL

Of the University of Colorado

No. 2045.-From the Proceedings of the United States National Museum, Vol. 47, pages $87-94$

Published May 7, 1914

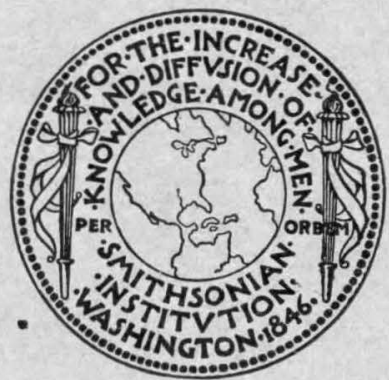

Property of G. E. BOHART

\section{Washington}

Government Printing Office

1914

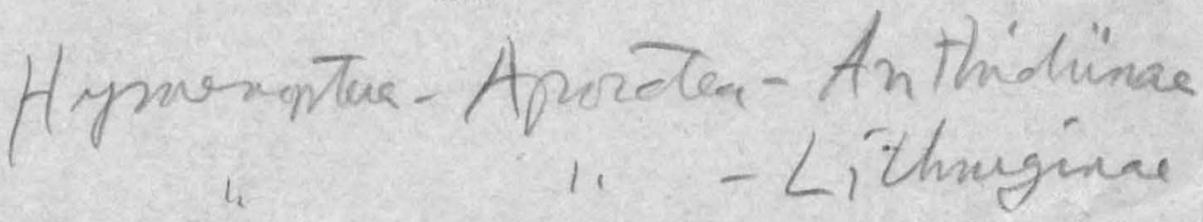




\section{NAMES APPLIED TO THE NORTH AMERICAN BEES OF THE GENERA LITHURGUS, ANTHIDIUM, AND ALLIES}

BY

T. D. A. COCKERELL

Of the University of Colorado

No. 2045.-From the Proceedings of the United States National Museum, Vol. 47 , pages $87-94$

Published May 7, 1914

Washington

Government Printing Office 1914 


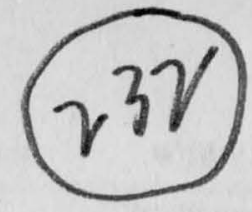

\title{
NAMES APPLIED TO THE NORTH AMERICAN BEES OF THE GENERA LITHURGUS, ANTHIDIUM, AND ALLIES.'
}

\author{
By T. D. A. Cockerell, \\ of the University of Colorado.
}

The Anthidiine and Lithurgine bees, representing two groups of Megachilidæ, are interesting on account of their habits, and frequently well-marked or even very peculiar structural characters. The Anthidiines, nearly always spotted or banded with yellow on the abdomen, are very well represented in our fauna, and are even to be found in the Miocene deposits of Colorado. Lithurgus, on the other hand, has only a few species in our fauna, although it is an old genus, found in the European Miocene, and widely spread over the earth, even to Australia and the islands of the Pacific.

\section{LIST OF SPECIES.}

\section{Genus ANTHIDIUM Fabricius,}

A genus of many species, found in most parts of the world, but absent from Australia and New Zealand.

The females use cottony fibers in making their nests, and are called by Fabre "Cottoniers."

For a discussion of the Palearctic genera and groups included by authors in Anthidium, see Entomologist's Record, vol. 21, No. 12.

TABLES.

(1) Cockerell, Bull. So. Cal. Acad. Sci., vol. 3, 1904, pp. 56-58. (Males.)

(2) Cockerell, Proc. U. S. Nat. Mus., vol. 40, 1911, p. 249.

(3) Friese, Das Tierreich, Megachilinæ, lief. 28, 1911, pp. 379-381.

(4) Friese, Das Tierreich, Megachilinæ, lief. 28, 1911, pp. 391-392.

(5) Cockerell, University of Colorado Studies, vol. 4, 1907, pp. 249-250.

(6) Swenk, University [of Nebraska] Studies, vol. 14, no. 1, 1913, pp. 9-11. americanum FrIESE, 1911. Tab. 4.

New name for $A$. maculatum Smith, preoccupied.

1 The asterisk $(*)$ indicates that the species is in the collection of the United States National Museum. Some species sent to the United States National Museum by Prof. T. D. A. Cockerell labeled "cotypes," are here listed as "paratypes," since Professor Cockerell uses the name "cotype" in the sense in which the museum uses "paratype." The museum has considerable material in the Anthidiine group and when this material is all determined the number of species in its collection will be considerably increased. Of the 107 names (fossil species omitted) in this list in the Anthidiine bees, 47 are represented by specimens in the collection. Of this 47,20 are types or paratypes.-J. C. Crawrord.

Proceedings U. S. National Museum, Vol. 47-No. 2045. 
*angelarum Trrus, 1906. Los Angeles County, California (Coquillett).

Female $9 \frac{1}{2} \mathrm{~mm}$.; markings deep yellow, scopa very white, sixth abdominal segment with large yellow spots.

Type.-Cat. No. 9034, U.S.N.M.

*astragali Swenk, 1913. Bad Lands at mouth of Monroe canyon, Sioux County, Nebraska. (M. Cary). Tab. 6.

Paratype.-Cat. No. 15259, U.S.N.M.

atrifrons Cresson, 1868. New Mexico (S. Lewis).

Same as emarginatum.

atriventre Cresson, 1878. California (Hy. Edwards). Tab. 3.

Female with ventral scopa and hair of face fuscous or black.

atriventre Sмгтн. 1879. Orizaba, Mexico.

Name preoccupied: =orizabæ.

aztecum Cresson, 1878. Mexico (Sumichrast). Tab. 4.

Allied to cognatum.

*banningense Cockerell. 1904. Banning, California (Davidson). Tab. 1. Male $14 \frac{1}{2} \mathrm{~mm}$.

*bernardinum Cockereld, 1904. Strawberry Valley, California (Davidson). Tab. 1. Male about $14 \mathrm{~mm}$; allied to $A$. pecosense.

Paratype.-Cat. No. 13666, U.S.N.M.

*bernardinum aridum Cockerell, 1904. Rock Creek, California (Davidson). Tab. 1. Scape of male yellow in front.

*bernardinum fragariellum Cockereld, 1904. Strawberry Valley, California (Davidson). Tab. 1.

Scape of male all black.

bernardinum wilsoni Cockerels, 1904. Mount Wilson, California (Davidson). Tab. 1. Male about $11 \mathrm{~mm}$.

blanditum Cresson, 1879. Nevada (Morrison). Tab. 2, 3.

Coxæ and trochanters (female) all black.

blanditum praedentatum Cockerell, 1907. Boulder, Colorado (G. Hite). Tab. 5 . Known (female) from $A$. montivagum and $A$. porteræ by the bright lemon-yellow sixth abdominal segment, its margin evidently notched in the middle, and the elongated marks over the eyes. Referred later to $A$. placitum as a variety.

californicum Cresson, 1879. California (H. Edwards). Tab. 1, 3.

Fowler describes the female from Berkeley and Redlands, California. Fox describes a variety from Lower California.

clypeodentatum SwENK, 1913. Sioux county, Nebraska. Tab. 6.

* cognatum Cresson, 1878. Georgia (Morrison). Tab. 3.

Characters: Trans. Amer. Ent. Soc., vol. 29, p. 175. Illinois (Robertson).

compactum Provancher, 1896. Los Angeles, California (Coquillett).

Name preoccupied: =collectum.

conspicuum Cresson, 1879. Nevada (Morrison). Tab. 3, 5.

Male: Entom. News, 1909, p. 262.

Also in Colorado.

collectum HUARD, 1896. Tab. 1, 3.

Allied to A. emarginatum; see Bull. Southern California Acad. Sci., May 1904, p. 73.

New name for $A$. compactum.

collectum ultrapictum Cockereld, 1904. Tehachapi, California (Davidson).

Male a little larger; scape with a yellow stripe; abdominal bands very bright yellow, only that on first segment divided into four spots.

crassipes Cresson, 1878. Florida (Tatnall). Tab. 3.

Ventral scopa yellowish; legs very robust.

edwardsii Cresson, 1878. California (Hy. Edwards). Tab. 3.

Dorsal hair of head and thorax dense and fulvous. 
* emarginatum SAx, 1824. Tab. 3, 5, 6.

Face of female black.

Cresson redescribes it from specimens collected in Kansas.

emarginatum atripes Cresson, 1879. Nevada (Morrison).

Male with legs entirely black.

exhumatum Cockerell, 1906. Fossil in the Miocene shales of Florissant (Scudder).

flavolineatum Sмгтн, 1879. Oajaca, Mexico=Dianthidium flavolineatum.

Female $8 \mathrm{~mm}$., a short narrow line behind the eyes yellow.

*harbecki Crawford, 1910. Wenonah, New Jersey (H. S. Harbeck).

Has a pulvillus, "Related according to the swollen legs to larreæ and to crassipes.

Outside of that one character it does not seem close to any others." (Crawford in letter.)

Type.-Cat. No. 13454, U.S.N.M.

This is to be referred to Heteranthidium on the authority of Mr. Crawford.

hesperium Swenk, 1913. Palo Alto, California.

hesperium dentipygum Swenk, 1913. Laramie, Wyoming.

*illustre Cresson, 1879. Nevada (Morrison). Tab. 3.

Fowler described the male from Redlands, California.

Nesting habits; Entom. News, 1904, p. 284.

This species is to be referred to Dianthidium.

illustre consonum Cresson, 1879. Nevada (Morrison).

impatiens Sмттн, 1879=Dianthidium impatiens. Tab. 4.

Male $8 \frac{1}{2} \mathrm{~mm}$.

incurvatum Swenk, 1913. Ute creek, Costilla County, Colorado (H. S. Smith).

jocosum Cresson, 1878. Colorado (Ridings). Tab. 3.

"A pretty little species, with the bands on apex of abdomen broad and uninterrupted." (Cresson.)

*lupinellum Cockerell, 1904. Pecos, New Mexico (W. P. Cockerell). Tab, 1. Male about $11 \mathrm{~mm}$; clypeus all yellow. Visits Lupinus.

Also in Texas.

maculatum SмIтH, 1854. Mexico.

Notes on type: Trans. Amer. Ent. Soc., vol. 21, p. 336.

Apex of male abdomen with long straight parallel blunt spines, the outer ones very much longer than the middle one; subapical lateral spines hooked.

Renamed A. americanum Friese, 1911.

maculifrons Sмгтн, 1854. "United States." Tab. 3.

*maculosum Cresson, 1678. "Utah (Putnam); California (H. Edwards)." Tab.2,3. Male; Ann. Mag. Nat. Hist., May 1900, p. 412.

montivagum Cresson, 1878. Colorado (Ridings). Tab. 2, 3.

mormonum Cresson, 1878. Utah (Ulke). Tab. 3.

nebrascense Swenk, 1913. Sowbelly canyon, Sioux County, Nebraska (R. W. Dawson). Tab. 6. Also in Wyoming.

orizabæ DALla TorRe=Dianthidium orizabæ. Tab. 4 .

Abdominal scopa black.

palliventre Cresson, 1878. California (Hy. Edwards). Tab. 1, 3.

Supposed male; Bull. Southern California Acad. Sci., April, 1904, p. 60.

palmarum Cockereld, 1904. Palm Spring, California (Davidson). Tab. 1.

Tegulæa apricot color.

paroselæ Cockerelu, 1898. Mesilla, Nex Mexico (Cockerell). Tab. 1.

Male: Ann. Mag. Nat. Hist., May 1900, p. 412.

Nesting habits; Minnie Newberry, Psyche, 1900, p. 94.

*pecosense Cockereld, 1904. Pecos, New Mexico (Cockerell). Tab. 1, 2.

Also at Flagstaff, Arizona (F. C. Pratt). 
perplexum Sмттн, 1854. Georgia. Tab. 3.

Legs and margin of thorax ferruginous.

This is to be referred to Dianthidium subgenus Anthidiellum on the authority of Mr. Crawford.

placitum Cressoon, 1879. Nevada (Morrison). Tab. 2, 3.

Female clypeus yellow except a median stripe; a yellow band behind ocelli, interrupted in middle.

placitum prædentatum Cockerell, 1907. Boulder, Colorado (G. Hite). Tab. 2, 5.

* porteræ Cockerell, 1900. Las Vegas, New Mexico (W. Porter). Tab. 1, 5.

Prior to 1900 confused with $A$. maculifrons.

Also in Texas, and north to Calgary in western Canada.

Type.-Cat. No. 5812, U.S.N.M.

"porteræ amabile Cockerell, 1904. Boulder, Colorado (Cockerell). Tab. 5.

Ground color of abdomen red.

Type.-Cat. No. 9655, U.S.N.M.

"porteræ personulatum Cockerell, 1907. Boulder, Colorado. (W. P. Cockerell). Tab. 5,6 .

Female clypeus entirely black; male with apical lobes and spine of abdomen black.

pondreum Trus, 1902. Fort Collins, Colorado (Titus). Tab. 2.

"pondreum," in the original publication, is a misprint.

Male (11 mm.) differs from atrifrons by the yellow markings, scape entirely black, and last abdominal segment deeply notched, with a blunt black tooth in middle. Variety (? hybrid with tenuifloræ); Ent. News, 1909, p. 262.

Also at Flagstaff, Arizona (Pratt).

praedentatum trianguliferum Swenk, 1913. Fort Garland, Costilla County, Colorado (L. Bruner).

*psoraleæ Robertson, 1902. Near Carlinville, lllinois (Robertson) Tab 6.

Characters: Trans. Amer. Ent. Soc., vol. 29, p. 175.

Face of female black.

*ridingsii Cresson, 1878. Georgia (J. Ridings). Tab. 3.

"A very distinct species, easily recognized by the abdominal fasciæ being very narrow and regular." (Cresson.)

This is to be referred to Heteranthidium on the authority of Crawford.

rodriguezi CockerelL, 1912. Guatemala (Rodriguez).

sagittipictum Swenk, 1913. Pullman, Washington(C. V. Piper).

sazorum Cockerell, 1904. Rock Creek, California (Davidson). Tab. 1.

Abdomen shining, with sparse punctures, the markings orange.

scudderi Cockerell, 1906. Fossil in the Miocene shales of Florissant (Scudder).

serranum Cockerell, 1904. Rock Creek, California (Davidson) Tab 6.

Male $15 \frac{1}{2} \mathrm{~mm}$. Comparison with illustre and conspicuum; Ent. News, 1909, p. 262; also Bull. Southern California Acad. Sci., Feb. 1904, p. 23.

*tenuifloræ Cockerell, 1907. Boulder, Colorado (W. P. Cockerell). Tab. 5, 6.

Allied to emarginatum; female ventral scopa sepia brown, pale at sides; male with dark tubercles and scutellum.

Also in Montana and western Canada.

titusi Cockerelu, 1904. Fort Collins, Colorado (E. S. G. Titus). Tab. 1, 5.

Allied to emarginatum.

transversum Swenk, 1913. Ute creek, Costilla County, Colorado (H. S. Smith).

*tricuspidum Provancher, 1896. Los Angeles, California (Coquillett). Tab. 1, 3.

Titus (1906) gives a new description.

*utahense Swenk, 1913. Logan, Utah.

Paratype--Cat. No. 15260, U.S.N.M.

wallisi Cockerelu, 1913. Peachland, British Columbia (J. B. Wallis).

Described in Canadian Entomologist, 1913, p. 13. 
Genus DIANTHIDIUM Cockerell.

A very widespread genus, rather more so than Anthidium, since there is one species in Australia.

The females use resin in making their nests, and are called by Fabre "Résiniers." Pulvilli are present on the feet of this genus, but absent in true Anthidium.

\section{SUbGenera AND Sections.}

Paranthidium T. and W. Cockerell, 1901.

Type.-Perpictum Cockerell.

Anthidiellum Cockerell, 1904.

Type.-Strigatum Panzer (European).

\section{TABLES.}

(1) Cockerell, Bull. Southern California Acad. Sci., vol. 3, 1904, pp. 3-4.

(2) Friese, Das Tierreich, Lief. 28, Megachilinæ, 1911, pp. 379-381.

(3) Friese, Das Tierreich, Lief. 28, Megachilinæ, 1911, pp. 391-392.

(4) Swenk, University [of Nebraska] Studies, vol. 14, No. 1, 1913, pt. 25-6.

agnatum Cresson, 1878. Mexico (Sumichrast). Tab. 3.

Wings fuliginous.

apicale Cresson, 1878. Mexico (Sumichrast). Tab. 3.

This, bivittatum and toltecum "are closely related, and have a short, broad, robust form somewhat like that of perplexum and notatum" (Cresson).

balli Trtus, 1902. Ridgeway, Colorado, July 31 (E. D. Ball).

Length $14 \mathrm{~mm}$., markings dark rich yellow; allied to venustum.

*bivittatum Cresson, 1878. Mexico (Sumichrast). Tab. 3.

Mesothorax with two yellow stripes.

Guatemala (Barber and Schwarz). Female described; Ann. Mag. Nat. Hist., July, 1913, p. 108.

boreale Robertson, 1902. Near Carlinville, Illinois (Robertson).

Allied to $D$. notatum; male $8 \mathrm{~mm}$; legs red, marked with yellow.

Characters: Trans. Amer. Ent. Soc., vol. 29, p. 175.

*concinnum Cresson, 1872. Texas (Belfrage). Tab. 2.

"Much like simile, differing principally by the color of the legs." (Cresson.)

The legs are fulvo-ferruginous.

Cotype-Cat. No. 1773, U.S.N.M.

*consimile Ashmead, 1896. Near Los Angeles, California (Davidson). 'Tab. 1.

Female $7 \mathrm{~mm}$.

Parasite; Torymus anthidii Ashmead.

The nest is figured and described in Ent. News, 1896, p. 23.

Type-Cat. No. 16698, U.S.N.M.

eressonii Dalla Torre, 1896. Tab. 2.

New name for venustum Cresson, preoccupied.

Nest: Bull. Amer. Mus. Nat. Hist., vol. 12, (1906), p. 444, fig. 1.

curvatum Sмттн, 1854. Georgia. Tab. 1.

This has been confused with sayi (interruptum Say).

*davidsoni Cockerell, 1904. Bear Valley, California (Davidson). Tab. 1.

Allied to parvum.

Type.-Cat. No. 9653 , U.S.N.M.

*ehrhorni Cockerell, 1900. Mojave Desert, California (Ehrhorn). Tab. 1.

Belongs to subgenus Anthidiellum.

Type.-Cat. No. 5811, U.S.N.M.

*eiseni Cockerell, 1913. San José del Cabo, Lower California (Eisen). Belongs to Anthidiellum.

Type.-Cat. No. 16225, U.S.N.M. 
flavolineatum Sмгтн, 1879. Oajaca, Mexico. Tab. 3.

formosum Cresson, 1878. Colorado (Ridings). Tab. 2.

Possibly the male of cressonii.

gabbii Cresson, 1878. Costa Rica (W. M. Gabb). Tab. 3.

*gilense CockereLL, 1897. West Fork of Gila River, New Mexico (Townsend). Tab. 1, 2.

Also in Texas.

Male: Ann. Mag. Nat. Hist., May 1900, p. 413.

Type.-Cat. No. 5810, U.S.N.M.

gualanense Cockerelu, 1912. Gualan, Guatemala (W. P. Cockerell).

illustre Cresson (see under Anthidium). Nevada (Morrison). Tab. 2.

impatiens Sмттн, 1879. "South Mexico." Tab. 3.

interruptum SAY, 1824. "Missouri."

Name preoccupied: = sayi.

*jugatorium SAY 1824. "Missouri." Tab. 4.

Very close to perpictum, differing in color of tegulæ.

*larreæ Cockereld, 1897. Near Agricultural College, Mesilla Valley, New Mexico (Cockerell). Tab. 2.

Legs red. Relationships; Bull. Southern California Acad. Sci., Feb., 1904, p. 23.

Type.-Cat. No. 3507, U.S.N.M.

lepidum Cresson, 1878. Georgia (Morrison). Tab. 2.

"Resembles jugatorium in ornamentation of abdomen" (Cresson).

*macrurum Cockerell, 1913. Federal District, Mexico (J. R. Inda).

Type.-Cat. No. 16226, U.S.N.M.

mexicanum Cresson, 1878. Mexico (Sumichrast). Tab. 3.

Wings fuscous.

*notatum Latrenle, 1809. "Carolina." Tab. 2.

Redescribed by Cresson, Proc. Ent. Soc. Phila., vol. 2, 1864, p. 376.

orizabæ Dalla Torre, 1896. Tab. 3.

New name for $A$. atriventre Smith, preoccupied.

*parvum Cresson, 1878. Colorado (Ridings). Tab. 1, 2.

"Marked very much like simile, but smaller" (Cresson).

*perpictum Cockereld, 1898. Ruidoso Creek, New Mexico (Wooton). Tab. 1.

Type,-Cat. No. 5807, U.S.N.M.

I have recently (Aug. 8, 1913) taken this at flowers of Helianthus annuus, at Boulder, Colorado.

perpictum coloradense Swenk, 1913. Colorado Springs, Colorado.

perplexum Sмгтн. See under Anthidium.

*provancheri Trtus, 1906. Los Angeles County, California (Coquillett).

"Closely allied to ulkei, ehrhorni, and simile" (Titus).

Type.-Cat. No. 9033, U.S.N.M.

pudens Cresson, 1879. Nevada (Morrison). Tab. 2.

"This may prove to be the female of pudicum" (Cresson).

*pudicum Cresson, 1879. Nevada (Morrison). Tab. 2.

Resembles $D$. parvum, but markings paler; perhaps not specifically distinct.

Female; Entomologist, May, 1907, p. 99.

*robertsoni Cockerell, 1904. Rock Creek, California (Duvidson). Tab. 1.

Belongs to subgenus Anthidiellum.

Type--Cat. No. 9654 , U.S.N.M.

* sayi Cockerell, 1907. Tab. 4.

New name for interruptum Say, preoccupied

sayi xerophilum Cockerell, 1907. Mesilla, New Mexico (Cockerell).

A very red form.

*simile Cressson, 1864. "Mass., Conn." Tab. 2. 
Varietal form or race in Texas; Proc. Ent. Soc. Washington, IX, p. 72.

singulare Cresson, 1879. Nevada (Morrison). Tab. 2.

"Easily recognized (female) by the dilated lateral margin of abdominal segments 2 to 4 " (Cresson). First two abdominal segments with the yellow bands divided into spots.

singulare perluteum T. and W. CockerelL, 1904. Wilson's Peak, California (Davidson).

First two abdominal segments with the yellow bands deeply notched, but not divided.

subparvum Swenk, 1913. Pullman, Washington (C. V. Piper).

tertiarium Cockerell, 1906. Fossil in the Miocene shales of Florissant (Scudder.)

*texanum Cresson, 1878. Texas (Belrage). Tab. ?.

Nest and female; Melander, Biol. Bull., 1902.

Allied to concinnum.

toltecum Cresson, 1878. Mexico (Sumichrast). Tab. 3.

*ulkei Cresson, 1878. Utah (Hy. Ulke). Tab. 2, 4.

Comparison with parvum; Entom. News, 1909, p. 261.

*ulkei perterritum Cockerell, 1913. Santa Fe, New Mexico (Cockerell).

venustum Cresson, 1878. Colorado (Ridings, Morrison).

Name preoccupied: = cressonii.

The following South American species are known to belong to Dianthidium:

D. inerme Friese.

D. bertonii Schrottky.

D. zebratum Schrottky.

D. bicoloratum Smith.

D. bicoloratum tucumanum Vachal.

D. steloides Spinola.

D. confusum Smith.

D. indescriptum Dalla Torre.

D. nudum Schrottky.

D. vernonix Schrottky.

D. megachiloides Holmberg.

D. heathi Cockerell.

D. iheringi Schrottky.
D. gregarium Schrottky.

D. gregarium continuifasciatum Strand.

D. tigrinum Schrottky.

D. anisitsi Schrottky.

D. paraguayense Schrottky.

D. multiplicatum Smith.

D. lunatum Smith.

D. joergenseni Friese (bruchi Schrottky).

D. brethesi Schrottky.

D. catamarcense Schrottky.

D. autumnale Schrottky.

D. nectarinioides Schrottky.

D. multifasciatum Strand.

Anthidium rubripes FrIEse, which Brethes (1909) referred to Dianthidium, is an Anthidium.

\section{Genus HYPANTHIDIUM Cockerell.}

Second recurrent nervure passing well beyond second submarginal cell, as in Dianthidium, but feet with no pulvilli.

aureocinctum Cockerell, 1912. Mexico.

*panamense Cockerell, 1913. Gatun, Canal Zone, Panama (A. H. Jennings.)

Type.-Cat. No. 16227, U.S.N.M.

The type of Hypanthidium is the South American H. Alavomarginatum Smith.

\section{Genus HETERANTHIDIUM Cockerell. ${ }^{1}$}

Second recurrent nervure meeting second transverse cubital, as in Anthidium; feet with pulvilli; end of male abdomen pointed. See also Ent. News, 1909, p. 261

*chippewaense Graenicher, 1910. Indian village at juncture of the Lower Tamarack and St. Croix Rivers, Minnesota (Graenicher).

Paratype.-Cat. No. 14915, U.S.N.M.

cockerelli Trtus, 1902. Rocky Ford (Gillette) and Virginia Dale (Titus), Colorado. Described under Protanthidium.

dorsale LePeletier, 1841. Georgia. This is the type of the genus.

Legs ferruginous; hair of thorax and head above rufous. 
harbecki Crawford. Sec under Anthidium.

*occidentale Cresson, 1868. New Mexico (S. Lewis).

Colorado (cf. Cresson).

ridingsi Cresson. See under Anthidium.

*zebratum Cresson, 1872. Texas (Heiligbrodt).

\section{Genus PROTANTHIDIUM T. and W. Cockerell.}

This is an Asiatic genus; the two American species (cockerelli and chippewaense) which have been referred to it belong to Heteranthidium.

\section{Genus TRACHUSA Jurine.}

A genus of Europe, represented in California by a single species, which departs from typical Trachusa, and approaches Dianthidium, in the venation. In general, however, it is remarkably like the European T. serratulæ.

perdita Cockerell, 1904. Tehachapi, California (Davidson).

Male about $12 \mathrm{~mm}$; abdomen black without light markings; clypeus and lateral face marks cream color.

\section{Genus LITHANTHIDIUM Cockerell.}

pertriste Cockereld, 1911. Fossil at Florissant, Colorado.

\section{Genus LITHURGUS Berthold.}

Fox (1902) has proposed to separate the North American species as a genus Lithurgopsis, but this can hardly be maintained. For an account of the characters of various species of Lithurgus, see Trans. Amer. Ent. Soc., vol. 31 (1905), p. 333.

Typical Lithurgus has no pulvillus in either sex; the males of Lithurgopsis have a distinct pulvillus.

*apicalis Cresson, 1875. "Colorado, New Mexico (H. C. Yarrow, C. E. Aiken)."

Hair at end of abdomen fulvous.

*apicalis opuntiæ Cockereld, 1902. Mesilla Valley, New Mexico (Cockerell).

Hair at end of abdomen dark. Formerly confused with gibbosus.

*compressus SмrтH, 1853. “United States" (Doubleday).

Apparently the male of gibbosus.

*echinocacti Cockereld, 1898. La Cueva, Organ Mountains, New Mexico (Townsend.)

Visits Echinocactus wislizenii.

*gibbosus SмrтH, 1853. "United States."

Female with the facial prominence not at all bilobed. oblongus Fox = Megachile longula.

Lithurgus is known from the European Miocene ( $L$. adamiticus Heer). It is represented in South America by the following species:
L. corumbæ Cockerell.
L. dubius Sichel.
L. laticeps Friese.
L. albiceps Friese.
L. rufiventris Friese.
L. pygmaeus Friese.
L. huberi Ducke.
L. planifrons Friese.
L. neoqueenensis Friese.
$L$. friese Ducke.
L. osmoides Friese.
L. macroglossa Friese. 
7 